Article

\title{
Classifying Dams for Environmental Flow Implementation in China
}

\author{
Ang Chen ${ }^{1,2} \mathbb{D}, \mathrm{Miao} \mathrm{Wu}^{3, *}$ and Michael E. McClain ${ }^{4}$ \\ 1 Department of Production \& Technology, Yangtze Ecology and Environment Co., Ltd., Wuhan 430062, China; \\ angteenchen@gmail.com \\ 2 State Key Laboratory of Simulation and Regulation of Water Cycle in River Basin, China Institute of Water \\ Resources and Hydropower Research, Beijing 100038, China \\ 3 College of Hydrology and Water Resources, Hohai University, Nanjing 210098, China \\ 4 IHE Delft Institute for Water Education, DA 2611 Delft, The Netherlands; m.mcclain@un-ihe.org \\ * Correspondence: 3water@hhu.edu.cn
}

Received: 28 November 2019; Accepted: 16 December 2019; Published: 21 December 2019

check for updates

\begin{abstract}
The implementation of environmental flows is of the utmost importance for ecosystem protection and restoration in dammed rivers. A key challenge in optimizing dam regulation is the uncertainty of the ecohydrology relationship between flow release and ecological response. In the present paper, we develop a framework of dam classification to organize the categories of the ecohydrology relationship for implementing environmental flows. Dams are classified from three major categories that differ in dam properties, hydrological alteration, and downstream hydrobiological diversities based on the relationship of hydrology and ecology. Finally, 773 dams in China are screened and ranked into four classes involving a great diversity of environmental flow components. A classification of dams that utilizes the implementation of environmental flows is presented. (1) Class 1 includes dams with rare and endangered fish species in the downstream. It is the category with the highest priority for environmental flow releases and regulation, requiring continuous flow and flood pulse components for fish spawning and migration. (2) Class 2 includes dams with significant hydrological alteration in the downstream. It is the category with second priority for environmental flow releases and regulation, requiring natural hydrological regimes simulation or complete flow component recovery for optimizing the flow duration curve and mitigating adverse impacts of dam operation. (3) Class 3 includes dams with a high degree of regulation where there is urgency for environmental flow releases and regulation, requiring that minimum flow is guaranteed by cascade reservoir regulation. (4) Class 4 includes dams with a low degree of regulation where there is less urgency for environmental flow releases and regulation. This classification method is important for future research, including environmental flow release regulation and the effectiveness evaluation of environmental flow adaptive management. It will be useful for guiding the implementation of environmental flows.
\end{abstract}

Keywords: adaptive management; environmental flow; hydrological alteration; rare and endangered fish species

\section{Introduction}

Worldwide hydropower installed capacity rose to $1247 \mathrm{GW}$, and annual average generating capacity was $4185 \mathrm{TWh}$ in 2016. There are about 50,000 reservoirs and dams ( $>15 \mathrm{~m}$ height) in the world, and millions of small reservoirs and dams [1]. For sustainable, clean, and cheap electricity under the Paris Agreement, and to mitigate climate change impacts and electricity shortage due to global population growth, dam construction will continue to increase. Global hydropower capacity 
may reach 2000 GW by 2050, and dam quantity and dimensions will continue to grow [2]. China is the world's largest producer of hydropower with the largest increase in installed hydropower capacity in the world [3]. In order to realize the benefits of flood control, hydroelectricity, shipping, water supply, and irrigation, dam construction in China has increased rapidly in recent decades. Natural river ecosystems have been negatively impacted by dam construction and operation, and natural hydrological regimes have significantly changed since the 1950s [4]. Global degradation of freshwater ecosystems, biodiversity, and flood plains are related to dams [5-7]. Therefore, it is critical to mitigate the ecological impacts of dams while maintaining social and economic benefits. It is also necessary to integrate multiple considerations, including water resources management, environment, energy, and finances, into a complex model in the initial planning period. "Hydropower by Design" is a promising solution to the traditional development mode [8]. During the design period, eco-environmental protection measures should be designed for dams [9,10]. During the operation period, mitigation and restoration measures should be applied in the impacted reaches. Although it is impossible to restore natural flow after dam operation, the flow has been significantly improved by releasing environmental flows.

Over the past decade, many methods have been developed to support the implementation of environmental flows [11]. A key challenge in optimizing dam regulation is the uncertainty of the ecohydrology relationship between flow release and ecological response. ELOHA (The Nature Conservancy) predicts the response of hydrological alterations by defining similarities between ecological and hydrological conditions, and can be used to establish environmental flow standards at regional scales [12]. With respect to large dams and rivers, the relationship between hydrology and ecology has been considered for environmental flow assessment in China [13]. Generally, research is continuously refined from downstream of dams to specific micro-habitats, and it is increasing in complexity and deepening from hydrological methods to holistic methods. However, there are still shortages in macro-scale e-flow management, with a continuously increased demand for monitoring data, technical methods, and financial support. A lack of monitoring data was the main reason for completely limiting implementation.

As one of the most essential measures in ecosystem protection and restoration in damming rivers, environmental flow has been the primary factor in plan environmental impact assessment (Plan-EIA) and environmental impact assessment (EIA) in China. However, environmental flow implementation is still the most difficult problem for authorities, scientists, and other stakeholders [14,15]. It is important to assess environmental flow timely, based on monitoring and ecohydrology relationships such as those formed for dam relicensing for improvement in dammed rivers in United States, and minimum flow requirements have been written in water laws $[16,17]$. Though environmental flow could be optimized through comprehensive policies and adaptive management, the implementation still takes too much time. In China, 10\% of the annual average flow was set as the minimum flow in EIA [18]. For different relevant environmental flow authorities in China, functional diversities in different dams were not considered enough due to the different management responsibilities, which made it difficult to determine priorities of flood control, hydroelectricity, irrigation, and ecological protection. The assessment framework of environmental flow provides perfect solutions based on scientific research, but it is difficult to apply in management due to complex indicators and a large amount of data [19]. There is no classified method in e-flow assessment, and implementation is the most critical problem in environmental flow management. The diversities of dam properties and functions, climate and morphology, and sensitive objects in the dammed reaches in environmental flow implementation should be taken more seriously.

Environmental flow assessment is mainly based on ecohydrology relationships and focuses on specific dams and sensitive objects. There is an urgent need for environmental flow management and classification methods, in order to improve the effectiveness and efficiency of environmental flow implementation in different dams. Therefore, we propose a classification framework for environmental flow implementation based on the indicators of dam properties, hydrological regimes, 
and hydrobiological characteristics. This paper aims to analyze the hydrological and ecological indicators that are significantly impacted by dam operation, and to provide dam classifications for guiding the implementation of environmental flows.

\section{Materials and Method}

\subsection{Classification Method}

\subsubsection{The Classification Framework}

Three categories of indicators are proposed to establish the classification framework for environmental flow assessment and implementation (Figure 1): dam properties, hydrological regimes, and hydrobiological characteristics. Based on data analysis of the three categories, the urgency of environmental flow release and the optimization in different dams were screened and ranked. The priorities were then determined for management.

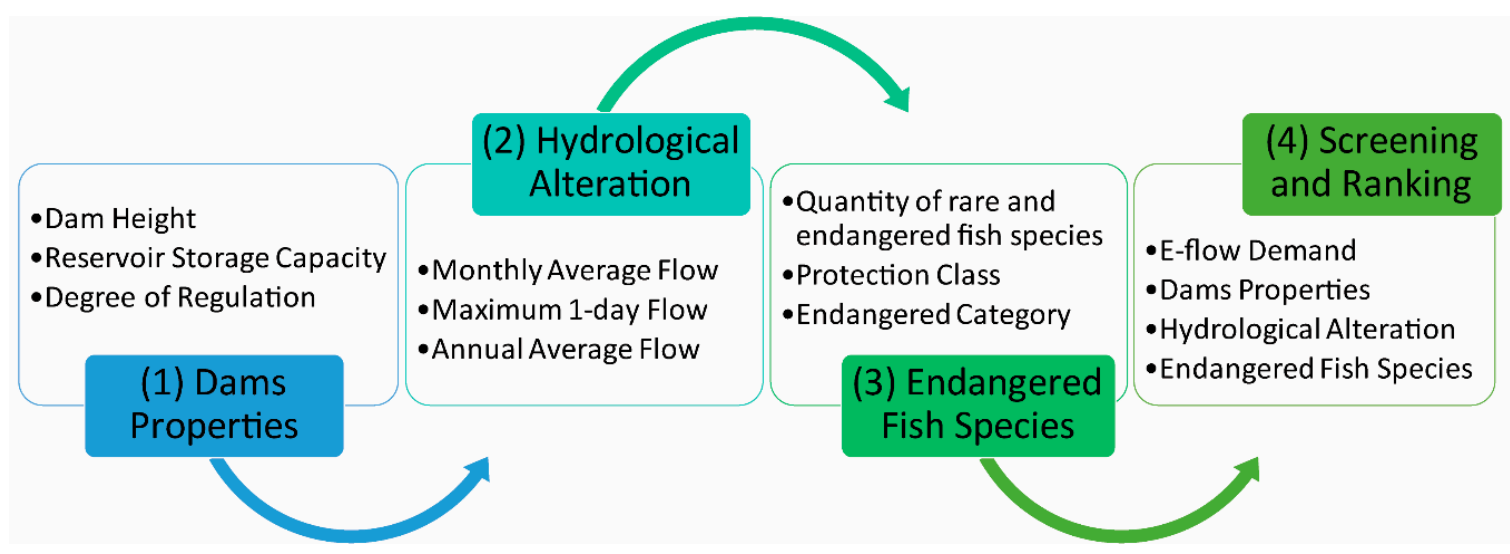

Figure 1. Dam classification framework for environmental flow implementation.

Firstly, dam properties were analyzed to estimate and assess the regulation performance of reservoirs. Based on studies based in California [20], development modes and main use were the two major and essential factors considered in this study, and reservoir storage capacity and degree of regulation (DOR) were chosen as classification indicators for dam properties.

Secondly, hydrological alterations were analyzed to assess the impacts of dam operation on the natural hydrological regimes. The range of observed flow before and after operation was analyzed to determine hydrological alterations, and observed flow data was collected from hydrological stations in the downstream of dams. Since the Indicators of Hydrological Alteration (IHA) has been shown to be effective [21], 14 hydrological alteration indicators were chosen from all indicators. Ranges of monthly average flow variability, the range of maximum 1-day flow variability, and the range of annual average flow variability were chosen as the specific quantitative hydrological indicators for hydrological alterations.

Thirdly, the quantity and protection class of rare and endangered fish species were analyzed to assess the impacts of dam operation on hydrobiology. Dam barriers might influence fish distribution and migration, and the loss of e-flow components has negative impacts on fish spawning and breeding. Because of the diversity of fish species in China, it is difficult to determine a unified environmental flow assessment criterion for fish species. From the main issue analysis of dam projects in China [22], the quantity, protection class, and the endangered category of rare and endangered fish species were chosen as specific hydrobiological indicators.

Dams were screened and classified based on this framework and were ranked by dam height, main use, degree of regulation, hydrological alteration, rare and endangered fish species categories, etc. 
As a result, a classification management list was made and applied in assessments and implementation, which can guide environmental flow management.

\subsubsection{Dam Property Indicators}

Dam property indicators present the disparity of dam height, main use, the degree of regulation, etc. Reservoir storage capacity $(\mathrm{V})$ and the degree of regulation $(\beta)$ were applied in this study.

\section{Reservoir Storage Capacity (V)}

A hydrological regime is nearly natural in free-flowing rivers and is regulated according to main use. The degree of impact depends on dam height, reservoir storage capacity, regulation rules, etc., which means little hydropower might also largely affect the natural flow [23,24]. However, the impacts of little hydropower are relatively slight compared with large dams because of the latter's large storage capacity. Therefore, reservoir storage capacity was identified and determined as one of the classification indicators.

Degree of Regulation $(\beta)$

Environmental flow regulation is also affected by reservoir regulation rules. According to main use, regulation performance was divided into annual flow regulation, monthly flow regulation, daily flow regulation, etc. Taking dam impacts on hydrological regimes and natural flow recovery into consideration, reservoir regulation performance was considered among classification indicators, and the degree of regulation (DOR) was also considered. The DOR is the ratio of utilizable capacity and annual average runoff [25].

$$
\beta=V_{u} / W \text {. }
$$

$\beta$ is the degree of regulation (\%), $V_{u}$ is the utilizable capacity $\left(\mathrm{m}^{3}\right)$, and $W$ is the annual average runoff in the dam site $\left(\mathrm{m}^{3}\right)$.

DOR presents the regulation performance of a dam and is strongly correlated with hydrological alteration indicators, such as peak flow reductions and seasonal flow variation [26]. Limited by the quantity and distribution of hydro-stations and flow data availability, the DOR is much more convenient and effective in hydrological alteration assessment when there is no flow data. Research has shown that the natural flow is significantly changed when $\beta$ is larger than 1 [27]. The DOR can be obtained from China Reservoirs and Dams (CR\&D), where $V_{u}$ and $W$ are dam properties, and the missing $W$ can be obtained by hydrological modelling. For example, three-arc-second HydroSHEDS data coupled with a WaterGAP2 hydrological model have been applied for simulating $W$ in California in the United States $[28,29]$. After comparing several runoff datasets, VIC (Variable Infiltration Capacity)-generated runoff data, which was in high precision after calibration, was selected for use in this study [30].

Considering cascade reservoir under the same regulation system and cascade regulation impacts, the cumulative degree of regulation (Cum.DOR) was also considered. Cum.DOR is the ratio (\%) of the total utilizable capacity of cascade reservoirs $\sum_{1}^{i} V_{u(x)}$ and the annual average runoff $W$ in the dam sites.

$$
\beta_{c}=\sum_{1}^{i} V_{u(x)} / W .
$$

\subsubsection{Hydrological Alteration Indicators}

The impacts of dam operation on hydrological regimes can be quantified by determining the percent deviation of selected indicators from the natural flow regime, while ecological monitoring data are needed for establishing ecohydrology relationships. Detailed methods to compare the flow before (pre-impact flow) and after dam (post-impact flow) operation include the Indicators of Hydrological Alteration (IHA) software and the range of variability approach (RVA) [31]. There is an extensive hydrological monitoring network in China, and there are hydro-stations below the dams. However, 
the data series of the hydro-station varies. For hydrological stations with insufficient data series, flow data can be obtained based on hydrological models, such as conceptual models and distributed hydrological models. The most popular hydrological models in China are the Xin'anjiang model, the Soil and Water Assessment Tool (SWAT), and VIC. As previously mentioned, VIC-derived flow data were applied in this study [32-34]. The input data for VIC were national rainfall, temperature, and wind data of $0.25 \times 0.25$, and the output flow data series was of 1952-2012. For this study, we applied a simplified measure of the degree of alteration of selected indicators from pre-impact to post-impact flow. Fourteen hydrological alteration indicators were considered and calculated in IHA software: Twelve indicators of the range of monthly average flow $\left(D_{m}\right)$, the range of maximum 1-day flow $\left(D_{\max }\right)$, and the range of annual average flow $\left(D_{a}\right)$.

Range of Monthly Average Flow $\left(D_{m}\right)$

There are twelve indicators of the range of monthly average flow $\left(D_{m}\right)$, one for each month of the year. $D_{m}$ is the ratio (\%) of post-impact monthly average flow and pre-impact monthly average flow, calculated using more than 20 years' flow data.

$$
D_{m(i)}=\left(Q_{o(i)}-Q_{n(i)}\right) / Q_{n(i)} .
$$

$Q_{o(i)}$ is observed post-impact monthly average flow $\left(\mathrm{m}^{3} / \mathrm{s}\right), Q_{n(i)}$ is observed pre-impact monthly average flow $\left(\mathrm{m}^{3} / \mathrm{s}\right) . i$ is the month under consideration.

Range of Maximum 1-Day Flow $\left(D_{\max }\right)$

$$
D_{\max }=\left(Q_{o(\max )}-Q_{n(\max )}\right) / Q_{n(\max )} .
$$

$Q_{o(\max )}$ is the observed post-impact maximum 1-day flow $\left(\mathrm{m}^{3} / \mathrm{s}\right)$, and $Q_{n(\max )}$ is observed pre-impact maximum 1-day flow $\left(\mathrm{m}^{3} / \mathrm{s}\right)$.

Range of Annual Average Flow $\left(D_{a}\right)$

The $D_{a}$ determination method is different from $D_{m}$ and $D_{\max }$. The Pearson product-moment correlation coefficient $(r)$ was applied for $D_{a}$ quantitative calculation by setting up regression analysis and correlation analysis of post-impact and pre-impact monthly average flow. We applied 0.5 as the threshold of annual average flow variability, and flow changed significantly while $r<0.5$.

$$
D_{a}=\frac{\operatorname{Cov}\left(Q_{o}, Q_{n}\right)}{\sigma_{Q_{0}} \cdot \sigma_{Q_{n}}} .
$$

$\operatorname{Cov}\left(Q_{0}, Q_{n}\right)$ is the covariance of the observed monthly average flow post-impact and pre-impact, and $\sigma_{Q_{0}} \cdot \sigma_{Q_{n}}$ is the product of the standard deviations of monthly average flows post-impact and pre-impact.

\subsubsection{Hydrobiological Indicators}

Hydrobiological indicators reflect the impacts of barriers on aquatic ecosystems, and rare and endangered fish species are most sensitive to, and indicative of, river ecosystem health changes [35]. Coupled with relevant objects of management authorities (e.g., Ministry of Ecology and Environment, Ministry of Agriculture), rare and endangered fish species are always of greatest concern. Fish species, especially the rare and endangered fish species and their habitats, are two of the major concerned hydrobiological indicators in the Plan-EIA and EIA of dam projects. After dam operation, rapid fish species and population degradation resulted from insufficient mitigation measures in the operation and regulation plans [36]. Although other species such as benthic macroinvertebrates indicate dam 
impacts [37,38], large-scale data are difficult to obtain. Therefore, the quantity, protection class, and the endangered category of rare and endangered fish species were selected as hydrobiological indicators.

The Quantity of Rare and Endangered Fish Species (n)

The quantity of rare and endangered fish species is a main constraint and limitation of dam construction, as rare and endangered species demand good aquatic conditions and a proper hydrological flow regime. After dam operation, e-flow below dams with downstream rare and endangered fish species is in demand, and certain multi-flow components, or a specific flow duration curve, that guarantee fish spawning and migration are required. An environmental flow duration curve depends on the quantity and distribution of rare and endangered fish species. Coupled with impacted segments of barriers on rare and endangered fish species, hot spots of China's inland freshwater fish diversity, endemic species and endangered species were intersected, and the dammed segments of high priority for fish habitat protection, which need to enhance e-flow discharge, can be determined.

Protection Class of Rare and Endangered Fish Species $\left(L_{\mathrm{P}}\right)$

The protection class in China is from the List of State Key Protected Wild Animals, which was approved by the State Council PRC in 1988. The protection class of important fish species in China is divided into two classes of protection by the State Council.

Endangered Category of Rare and Endangered Fish Species $\left(L_{\mathrm{E}}\right)$

The endangered category represents the population changes of rare and endangered fish species. There are many reasons why endangered fish increase, including fishery over-exploitation, water pollution, habitat loss resulting from water resource exploitation and hydropower development, etc. According to the China Red Data Book of Endangered Animals: Pisces, there are four categories: extinct (4 species), rare (23 species), endangered (28 species), and vulnerable (37 species). Species falling into these categories include 52 species of carp, 11 species of clam, 5 species of sturgeon, 6 species of salmon trout, and 18 other species (e.g., eel). In addition, the IUCN red list also provides a reference for classification in this study.

\subsubsection{Screening and Ranking}

This is a synthesis of existing techniques and expert experience to rank the dams. It consists of 4 main components according to the classification framework, so as to rank dams based on real and potential impact. Through the above calculations, we can obtain the level of each attribute and account for the possibilities of any dam. Considering all dam types, the different attribute levels are arranged and combined according to expert knowledge. In order to screen the dams and simplify the framework, all types need to be ranked according to these attributes. In this study, dams were screened after analysis of classification indicators, and the contribution of impacts on environmental flow release and regulation was ranked according to the three categories as follows: dam height $(>1.8 \mathrm{~m})$, reservoir storage capacity $\left(>1\right.$ billion $\left.\mathrm{m}^{3}\right)$, main use, the degree of regulation, hydrological alteration, and the rare and endangered fish species category (Protection Class I \& II, endangered category (EN)).

Environmental flow management classes were determined based on the three categories, and could be divided into four classes. Each class supported ecohydrology relationships and environmental flow management. Items could be included in the same class, while dam variables reached a threshold of the indicators, and all the last dams could be included in the fourth class. The setting of indicator thresholds depends on the impacts on the hydrological regime and fish species (Table 1). Except for the quantitative indicators and criteria, indicators such as main use of the dam were also considered for identifying main use. Research on flow alterations in global dammed rivers showed that threshold might be $20-50 \%$ [39]. Therefore, we applied $50 \%$ as the threshold of $D_{m}$ and $D_{\max }$ for river ecosystem health in this study. For the range of annual average flow variability, we hypothesized that $r \geq 0.75$ was a good condition, $0.75>r \geq 0.5$ was a normal condition, and $r<0.5$ was a bad condition. 
Table 1. Screening and ranking criteria.

\begin{tabular}{|c|c|c|}
\hline Category & Indicators & Criteria \\
\hline \multirow{3}{*}{ Dam properties } & Dam height & $\geq 1.8 \mathrm{~m}$ \\
\hline & Reservoir storage capacity & $\geq 1$ billion $\mathrm{m}^{3}$ \\
\hline & The degree of regulation & $\geq 0.02$ \\
\hline \multirow{3}{*}{$\begin{array}{l}\text { Hydrological } \\
\text { alteration }\end{array}$} & The range of monthly average flow variability & $\geq 0.5$ \\
\hline & The range of maximum 1-day flow variability & $\geq 0.5$ \\
\hline & The range of annual average flow variability & $\geq 0.75$ \\
\hline \multirow{3}{*}{$\begin{array}{l}\text { Hydrobiological } \\
\text { characteristics }\end{array}$} & The quantity of rare and endangered fish species & $n>0$ \\
\hline & $\begin{array}{l}\text { The protection class of rare and endangered } \\
\text { fish species }\end{array}$ & $\begin{array}{l}\text { Protection Class: I } \\
\text { Protection Class: II }\end{array}$ \\
\hline & $\begin{array}{l}\text { The endangered category of rare and endangered } \\
\text { fish species }\end{array}$ & $\begin{array}{l}\text { Critically Endangered (CR) and } \\
\text { Endangered (EN) included, } \\
\text { Vulnerable (VU) considered. }\end{array}$ \\
\hline
\end{tabular}

\subsection{Data Preparation}

\subsubsection{Dam Data}

According to the Bulletin of First National Census for Water, there were 98,002 reservoirs (storage capacity $\geq 100,000 \mathrm{~m}^{3}$ ) and 46,758 hydropower stations by the end of 2011, including 756 large reservoirs, 3938 medium reservoirs, and 93,308 small reservoirs [40]. China's Reservoirs \& Dams Database (CR\&D, Tables S1 and S2) was built by integrating several existing datasets, including the Global Reservoirs and Dams database (GRanD) from the Global Water Systems Project (dam height $>1.8 \mathrm{~m}$ and reservoir capacity $>60,000 \mathrm{~m}^{3}$ ) [41,42], a database of dam projects approved by China's Ministry of Ecology and Environment since 2001, etc. By identifying and revising dam coordinates, a GIS format layer and an attribute table were established based on the ArcGIS 10.3 platform based on the National Basic Geographic Database and true orthorectified satellite images. There was a total of 773 dams in CR\&D after revision and editing by comparing with relevant literature and open government sources. The statistical indicators were dam name, basin, administrative region, operated date, dam height, reservoir storage capacity, and main use.

\subsubsection{Hydrological Data}

Hydrological data are mainly river reach layers, hydro-station layers, and flow data. The river reach layers are from the National Basic Geographic Database, including five level reaches and administrative areas. The hydro-station location data are from China's hydrological station distribution map, including 9154 hydro-stations (data source: http://www.resdc.cn). According to the dam distribution map, downstream hydro-stations were identified. At the same time, taking dam operation time into account, we checked that there were flow data available from the hydro-stations before the dam operated. Although China's hydro-stations are widely distributed, typical hydro-stations representing the dammed impacts on the flow were not abundant. After analysis and integration of the hydro-station distribution map, the dam distribution map and the national river reaches map, 367 hydro-stations in the downstream of the dams were identified in Google Earth. Observed flow data of hydro-stations were collected from the Yearbook of Hydrology and Water Resources Bulletin, and the missing flow data were generated by the VIC model instead.

\subsubsection{Hydrobiological Data}

According to the China Red Data Book of Endangered Animals: Pisces and the List of State Key Protected Wild Animals, 16 protected fish species and 92 rare and endangered fish species were identified in this study, including their protection class and endangered category (Tables S3-S5). 
China's inland freshwater fish studies began in the 1970s, but large-scale fish distribution research and GIS (geographic information system) integrated studies are relatively scarce due to fish migration and river reaches. Even though a GIS-based fish geo-spatial database was established in some research [43], they were at more of a regional distribution than a reach distribution and took little account of reach diversity. This study aimed to classify the impact of barriers on fish species, and it is necessary to identify the relationship between specific dam projects and rare and endangered fish species. Through literature retrieval, we determined our method based on Santos et al. [44], who divided the distribution of rare and endangered fish species into the 1-5 grade river reach layers in China. Dam layers were overlain to determine fish habitat rescue protection segments (Table S6), and fish species, protection class, and the endangered category were assigned into the attribute table of the layers.

\section{Results}

\subsection{Classification of Dam Properties}

There are differences in dam classification between China and many other countries. Dams in China are classified mainly based on the storage capacity and safety level, while dams in other countries are more commonly classified based on dam height or dam break risk. According to ICOLD's definition, a large dam has a height larger than $15 \mathrm{~m}$ or a height of $5-15 \mathrm{~m}$ with a reservoir storage capacity of more than 3 million $\mathrm{m}^{3}$. Dam heights in this study were ranked into $0-5 \mathrm{~m}, 5-15 \mathrm{~m}, 15-30 \mathrm{~m}$, 30-60 m, 60-100 m, 100-200 m, and >200 m, and storage capacity was ranked into 0.1-1, 1-10, 10-100, 100-1000, and $>1000$ million $\mathrm{m}^{3}$. Our results reveal that all 773 dams in the CR\&D may be classified from medium to large. The largest number of dams are 30-60 m high, and have reservoirs with a storage capacity between 10 and 100 million $\mathrm{m}^{3}$. Four hundred twenty-six dams had a clear main use, the most common of which was irrigation (Figure 2).
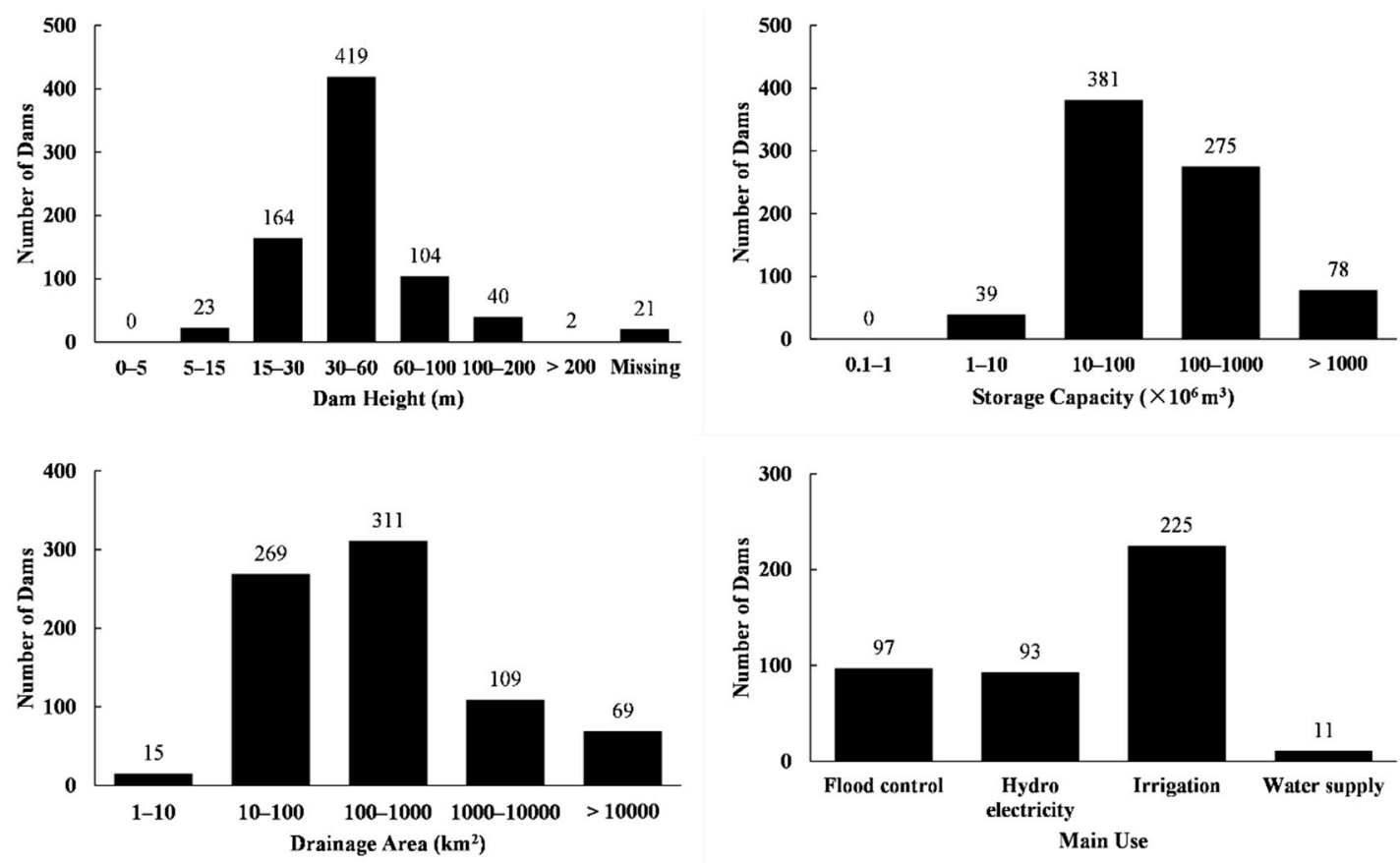

Figure 2. Dam classification based on dam properties.

For the degree of regulation, it is considered that $\beta<0.02$ is no regulation, $0.02-0.08$ is seasonal flow regulation, $0.08-0.3$ is annual flow regulation, and larger than 0.3 is multi-year flow regulation. $\beta$ is about 0.5 for reservoirs with irrigation as the first priority development target. The impacts of run-of-river hydropower stations and daily flow regulated hydropower stations on flow alteration were both small compared with annual flow-regulated hydropower stations and multi-year flow-regulated 
hydropower stations. However, a higher degree of flow-regulated hydropower stations can optimize the distribution and regulation of monthly and annually runoff, and hydroelectricity and water storage for e-flow could be balanced. Therefore, e-flow regulation should be applied in most dams with higher $\mathrm{V}$ and $\beta$, which were calculated in CR\&D. The results showed that most dams and reservoirs in the $C R \& D$ are multi-year flow regulation types, the $\beta$ of 587 dams was larger than 0.5 , the $\beta$ of 491 dams was larger than 0.75 , and the $\beta$ of 227 dams was larger than 2 . Dams with large $\beta$ values were mainly located in the Liaohe River Basin, the Haihe River Basin, the Yangtze River Basin, and the Southeastern River Basin (Figure 3).

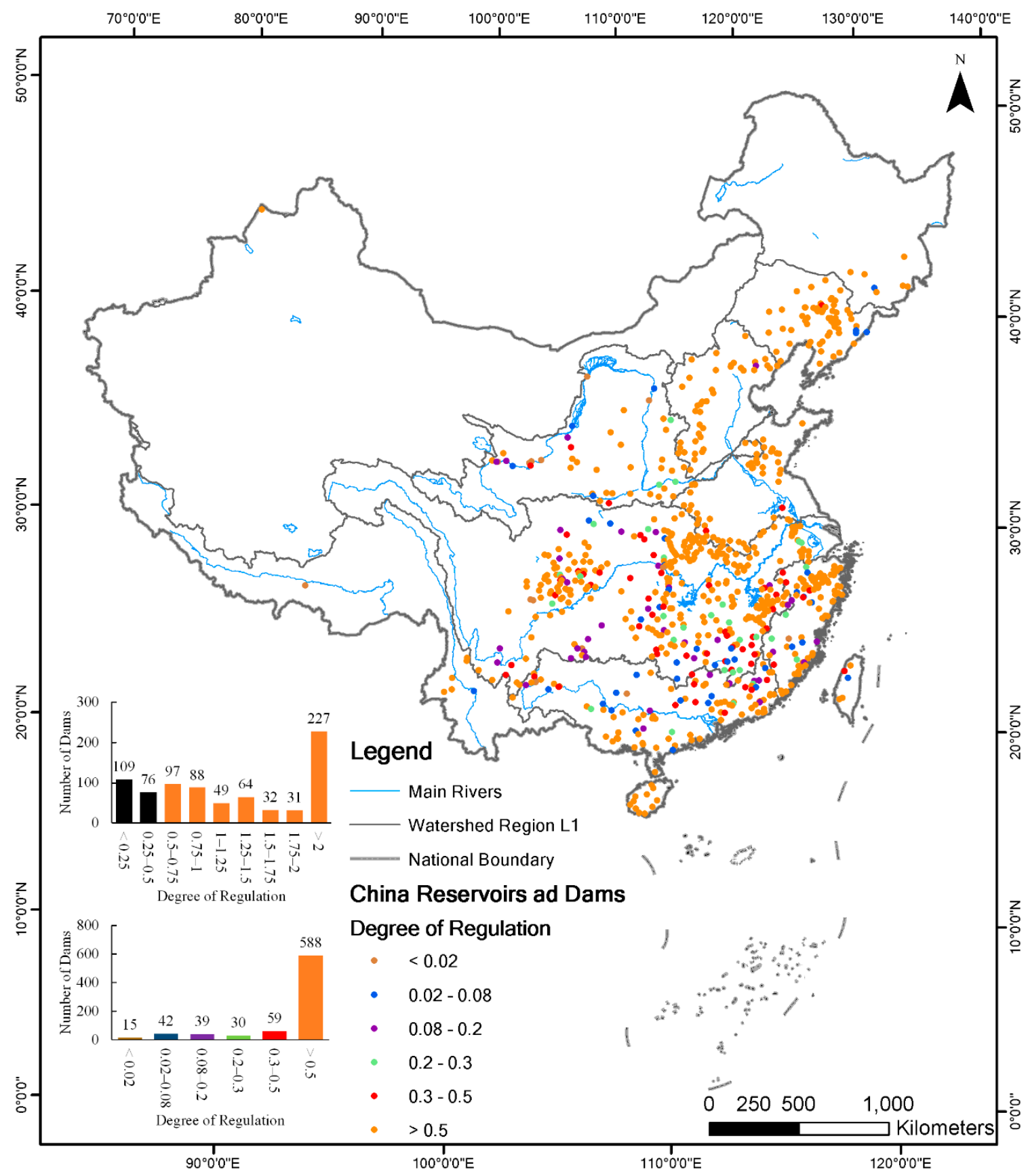

Figure 3. Dams and $\beta$ distribution. 


\subsection{Classification of Hydrological Alteration}

Results show alterations of downstream hydrological regimes after dam operation. Eight typical dam projects with different main uses, including flood prevention, hydroelectricity, and irrigation, and different degrees of regulation, including annual flow regulation, seasonal flow regulation, and daily flow regulation, were analyzed in this study (Table 2). Fourteen ranges of variability indicators were calculated for each dam project before and after dam operation.

Table 2. Typical dam characteristics.

\begin{tabular}{cccccc}
\hline No. & Dam Name & $\begin{array}{c}\text { 1st Priority } \\
\text { Development Target }\end{array}$ & $\begin{array}{c}\text { Regulation } \\
\text { Performance }\end{array}$ & $\begin{array}{c}\text { Operation } \\
\text { Time }\end{array}$ & $\begin{array}{c}\text { Observed } \\
\text { Flow Data }\end{array}$ \\
\hline 1 & Three Gorges & Flood control & $\begin{array}{c}\text { Incomplete seasonal } \\
\text { flow regulation }\end{array}$ & 2003 & $1982-2014$ \\
\hline 2 & Xiaolangdi & Flood control & $\begin{array}{c}\text { Incomplete annual } \\
\text { flow regulation }\end{array}$ & 2002 & $1987-2014$ \\
\hline 3 & Liujiaxia & Hydroelectricity & $\begin{array}{c}\text { Incomplete annual } \\
\text { flow regulation }\end{array}$ & 1968 & $1956-1986$ \\
\hline 4 & Er'tan & Hydroelectricity & $\begin{array}{c}\text { Seasonal flow } \\
\text { regulation }\end{array}$ & 2000 & $1953-2012$ \\
\hline 6 & Shiquan & Hydroelectricity & $\begin{array}{c}\text { Incomplete seasonal } \\
\text { flow regulation }\end{array}$ & 1973 & $1956-1986$ \\
\hline 7 & Bapanxia & Hydroelectricity & Daily flow regulation & 1975 & $1967-1987$ \\
\hline 8 & Hemianshi & Irrigation & $\begin{array}{c}\text { Incomplete seasonal } \\
\text { flow regulation }\end{array}$ & 1974 & $1956-1984$ \\
\hline
\end{tabular}

\subsubsection{Range of Monthly Average Flow Variability $\left(D_{m}\right)$}

$D_{m}$ varied greatly among different dams, and $D_{m}$ of Xiaolangdi, Liujiaxia, Gaoguang, and Hemianshi were higher than 0.5 in several months. For dams with flood control as the main development target, $D_{m}$ was usually less than 0.5. Among them, the $D_{m}$ of Xiaolangdi in June was very high mainly because of water-sediment regulation. For dams with irrigation as the main development target, $D_{m}$ was very high in irrigation months, due to increased agricultural water abstractions (Figure 4).
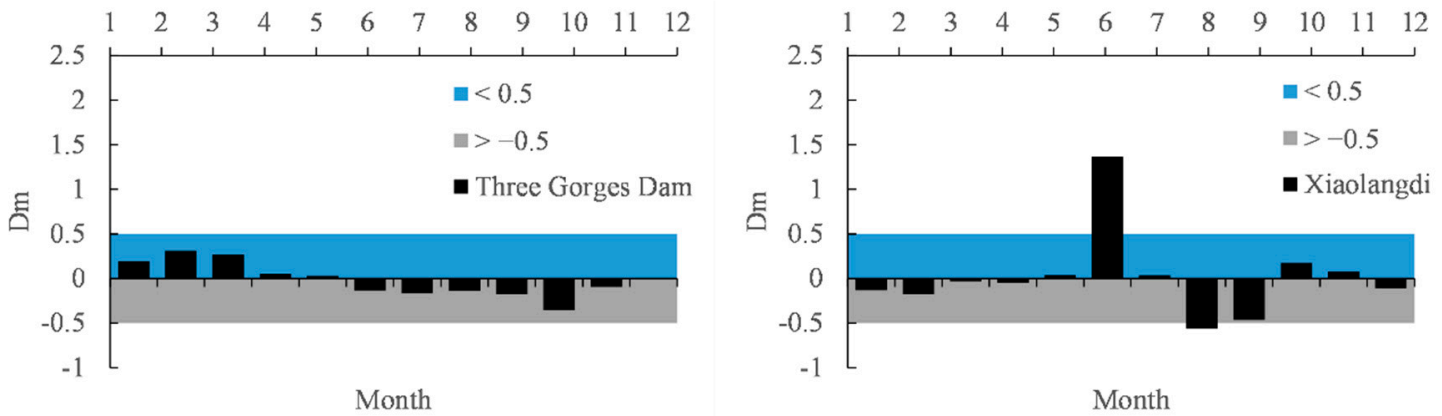

Figure 4. Cont. 

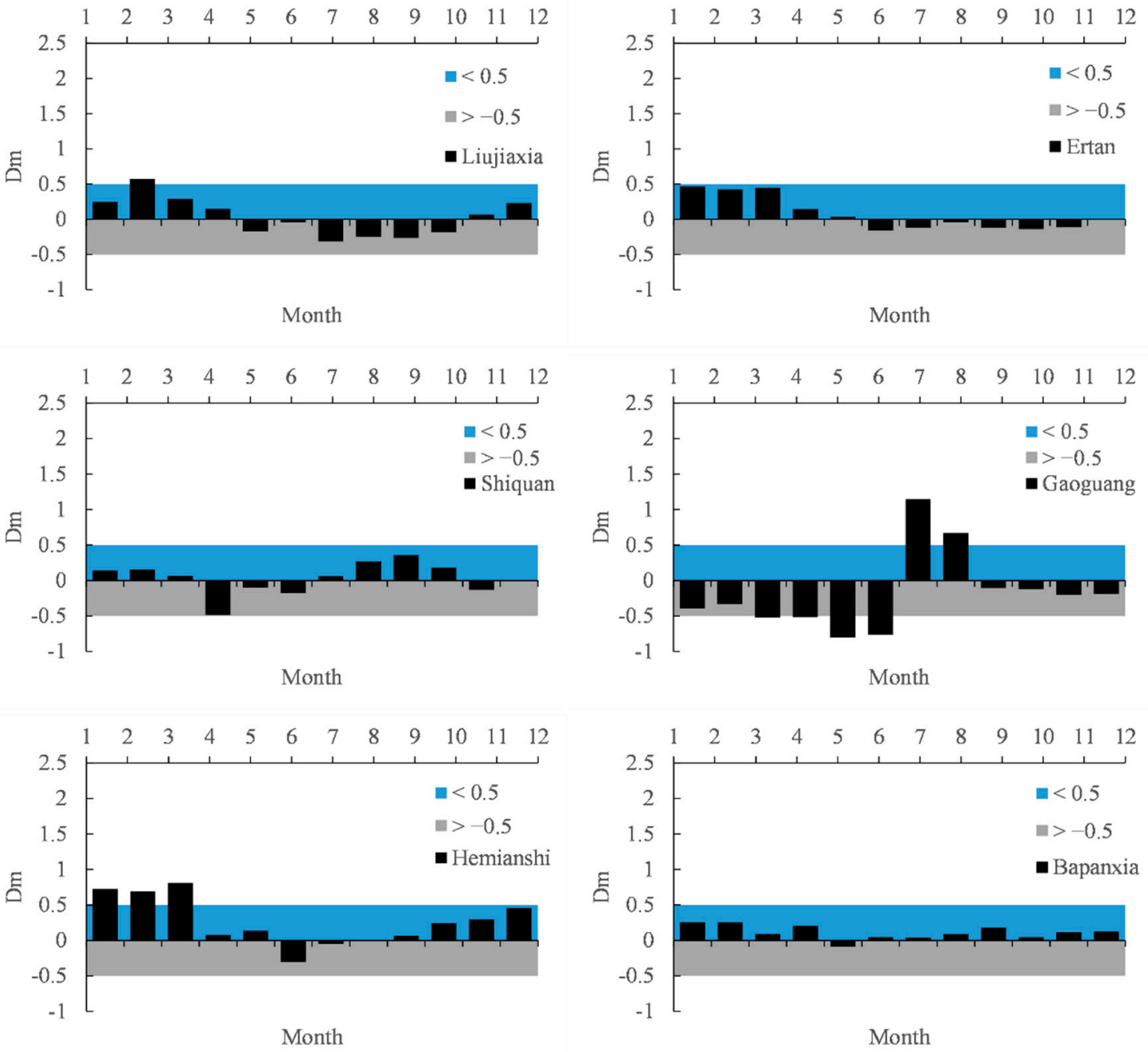

Figure 4. Range of monthly average flow variability.

\subsubsection{Range of Maximum 1-Day Flow $\left(D_{\max }\right)$}

The change in the maximum 1-day flow indicates the degree of peak load shaving after dam operation. The reduction of maximum 1-day flow or flood peak flow has adverse impacts on the stimulation of fish spawning and floodplain overbank process. For example, the $D_{\max }$ of Xiaolangdi was -0.41 mainly due to the reduction of large and medium floods (Figure 5).

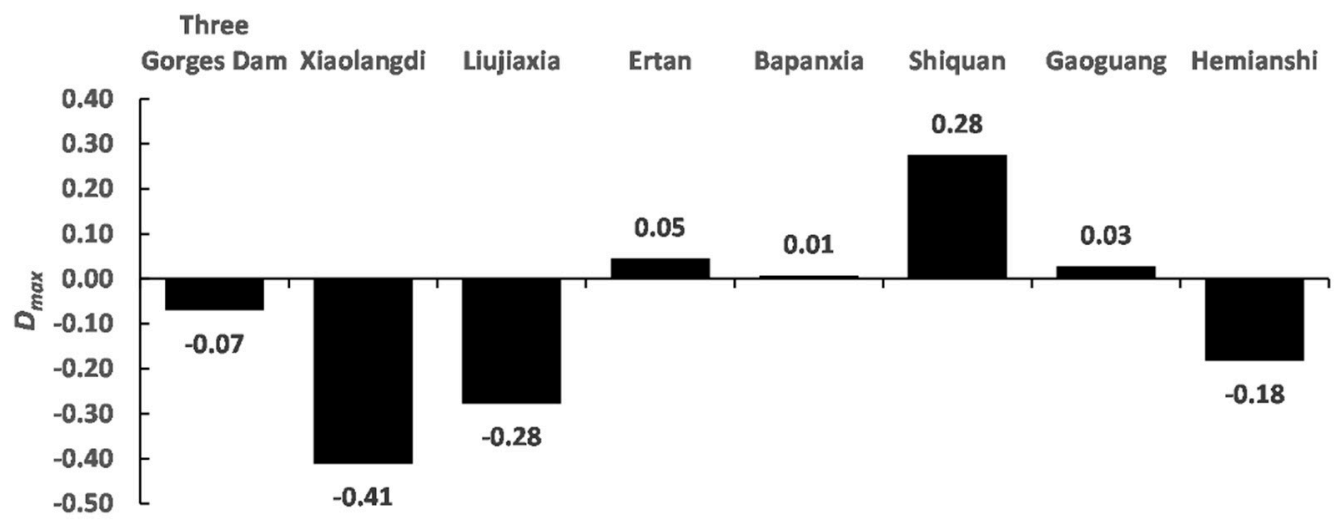

Figure 5. Range of maximum 1-day flow variability. 


\subsubsection{Range of Annual Average Flow Variability $\left(D_{a}\right)$}

$D_{a}$ was determined based on $r$ analysis. The results showed that the $D_{a}$ of most dams were not significant $(r>0.9)$ and kept annual flow components before dam operation. $D_{a}$ of several dams were relatively significant $(r<0.5)$. For example, flow alterations showed negative correlation in the Xiaolangdi dam, and this is mainly a result of the operation and regulation of storing and discharging muddy water (Figure 6).
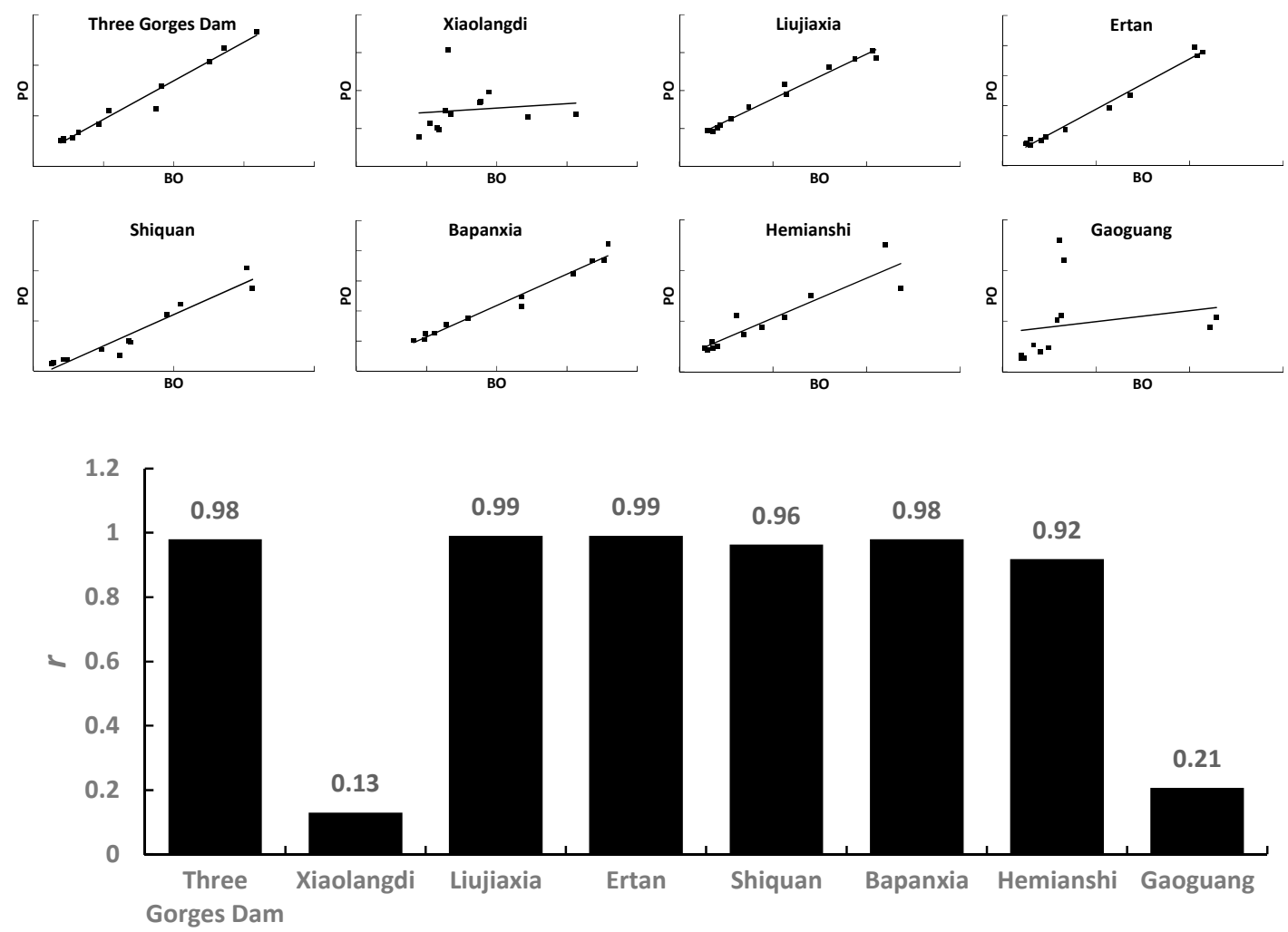

0.92

Figure 6. Range of annual average flow variability. Note: BO: before operation; PO: post-operation; $r$ : correlation coefficient.

\subsection{Classification of Hydrobiological Indicators}

The distribution of segments containing rare and endangered fish species was identified (Tables S7 and S8). As a result, there were three major distribution areas for 92 endangered fish species, most of them were species endemic to China. The first area included the mainstream and tributaries of the Yangtze River, especially the middle and upper reaches of the Yangtze River. The second area included the Lancangjiang River, the Nu River, and Dianchi Lake in Yunnan. The third area included the Heilongjiang River and the Wusulijiang River in Northeast China. In addition, some species were distributed in the Tarim River in Xinjiang as well as in the middle and upper reaches of the Yellow River. The endangered category and distribution data of rare and endangered fish species were assigned into the ArcGIS attributes table on the basis of the IUCN endangered category. After overlaying layers of rare and endangered fish species distribution and dam distributions, 27 dams with rare and endangered species in the downstream were identified, among which were eight species in the downstream of the Manwan dam in the Lancangjiang River and five species in the lower reaches of the Three Gorges Dam and the Gezhouba Dam in the Yangtze River (Figure 7). Though there were more rare and endangered fish species in the Lancangjiang River, the highest protection class was II, while the highest endangered category was VN. There were fewer rare and endangered fish species in the lower reaches of the Yangtze River, but the protection class and endangered category were relatively 
higher, including the national protection fish species white sturgeon (Protection Class I, CR), Chinese sturgeon (protection class I, CR), and Chinese high fin banded shark (Protection Class II, EN).

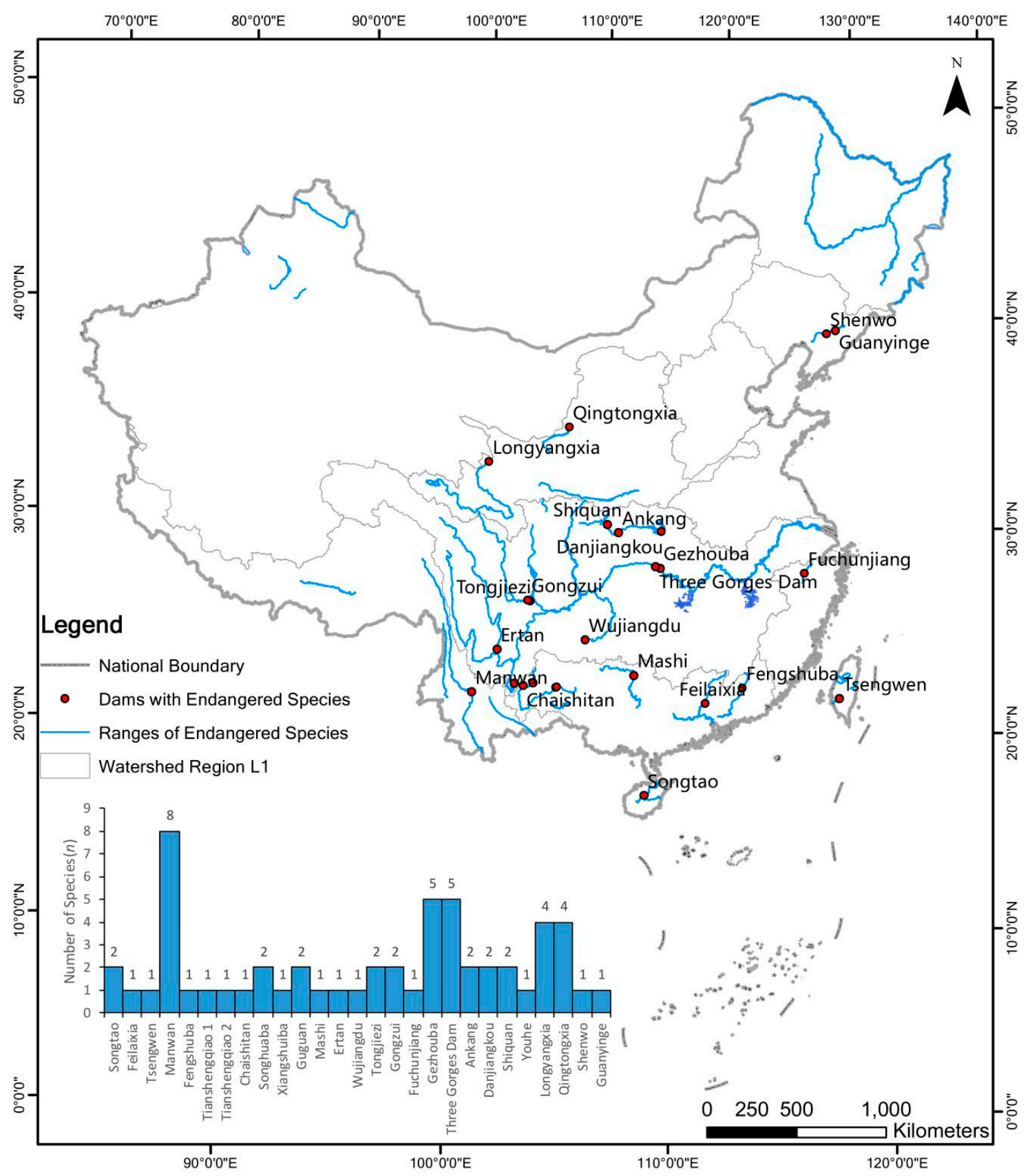

Figure 7. Dam distribution with rare and endangered fish species in the downstream.

\subsection{E-Flow Management Classes}

As a result, a classification management list was made and could be applied in e-flow assessment and implementation. Based on the above three categories, dams were screened and ranked to a classification list. The rare and endangered fish species were mainly distributed in the mainstreams of large rivers. By overlaying the hot spot layers of fish diversities with the maps of dam distribution and fish habitat rescue protection segments, priority segments of fish habitats protection were identified and determined. For these segments, ecological regulation should be implemented through cascade reservoirs regulation for e-flow optimization. There are fewer endangered fish species in the tributaries with small hydropower stations, and the degree of regulation and hydrological alteration should have 
more attention paid to it in e-flow assessments. As a result, four management classes were established for e-flow assessment and implementation (Figure 8).

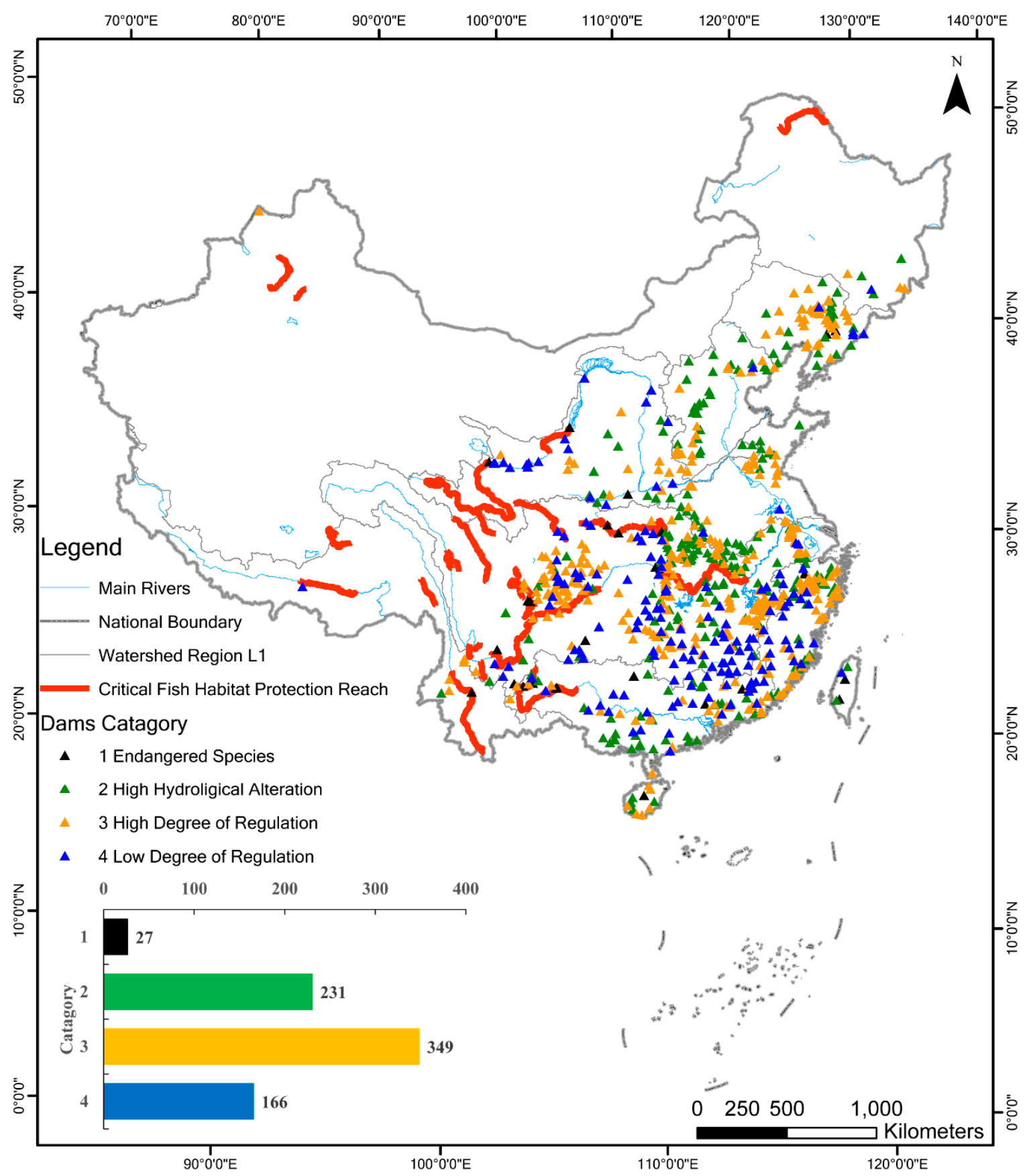

Figure 8. Management classes for environmental flow assessment and implementation.

(1) Class 1: dams with rare and endangered fish species in the downstream. Dams in this class should consider e-flow more for fish spawning, migration, and other sensitive ecological water demands. Integrated with reservoir regulation performance or cascade reservoir regulation, e-flow adaptive management should be promoted in these dams for fish species to be able to complete their life cycle, including spawning and breeding. We identified 27 dams out of the total of 773 dams that have national rare and endangered fish species in their downstream reaches. Meanwhile, if China's endemic fish species and provincial conservation fish species are considered, there would be many more dams in Class 1 . Species that are extinct in the wild with no possibility of recovery by ecological 
regulation, such as the white sturgeon, were not considered in this study. Other species such as the Chinese sturgeon and four major Chinese carps have already recovered by the regulation of a cascade of reservoirs in the middle and lower parts of the Yangtze River. Some species such as the Chinese high fin banded shark and Sichuan taimen were not in a high protection class or endangered level, but the existing population was relatively small and required further protection based on e-flow discharge and regulation.

(2) Class 2: dams with significant hydrological alterations in the downstream, especially those with a $D_{m}$ and $D_{\max }$ larger than 0.5 . For these dams, e-flow component recovery was the major target besides main use. In this study, we considered dams with a $\beta$ larger than 0.5 , a V larger than 100 million $\mathrm{m}^{3}$, and a dam height larger than $30 \mathrm{~m}$ to have more impacts on downstream flow variations. In order to mitigate the adverse impacts, the main use of flood control, hydroelectricity, and irrigation should be combined into systematic allocations of e-flow water and guaranteed measures. E-flow could then be guaranteed under insufficient reservoir inflow conditions.

(3) Class 3: dams with a high degree of regulation. Since dam height did not directly connect to hydrological alteration, the reservoir storage capacity was large for the numbers of dams of which the $\beta$ and the range of hydrological alterations were very high. Therefore, hydrological alteration was considered significant when $\beta>0.5$, and 0.5 was set as the threshold for e-flow management. For these dams, a minimum e-flow should be guaranteed and could be regulated and achieved by controlling the discharge.

(4) Class 4: dams with no regulation and daily flow regulated hydropower stations with a low $\beta$. Mostly, rare and endangered fish species and other ecological sensitive objects were not distributed in the downstream reaches of these dams. E-flow assessment is not emphasized for these dams because downstream flow regimes have not been significantly altered.

\section{Discussion}

In addition to the intended and desirable effects of dams, numerous studies have also documented their adverse consequences, including impacts on hydrological connectivity [45], flow regulation [41], sediment delivery [46], and biodiversity [47]. In order to mitigate the impacts, environmental protection measures have been planned and designed in damming rivers, such as e-flow, fishway passages, fish habitat protection measures, etc. [48]. Large dams reduce fish diversity but also block fish migration that connects populations and enables species to complete their life cycles. The released flow by e-flow implementation is effective in recovering fish spawning productivity for fish biodiversity protection, which has been proved in the Three Gorges Dam [49]. Watershed scale e-flow could be protected by enhancing the water licensing [50], and it is necessary to integrate multi-models that consider water resource management, the environment, energy, and finances into a dam model in the planning period from project scale to watershed scale. There is still no systematic conservation plan over the entire process or at the basin scale in China. The hydropower designs proposed by TNC and the Systematic Conservation Plan proposed by the WWF were both very good policies for river ecosystem protection and for e-flow implementation [51]. However, they have not been applied in operation periods for building ecohydrology relationships. The river hydropower plans have mostly been finished already and the current urgency relates to how e-flow can be managed and optimized in operation period. The e-flow implementation in China is critical because the threshold value of minimum flow $(10 \%$ of annual average flow) is still the basis for e-flow implementation and supervision, and there is no classified consideration for different dams. Categories can be better formed on the basis of this study, and indicators are the most important.

Dam projects can be classified into many different types in different countries in the world, and have been mastered by many different ministries in China. Hydropower projects have been mastered by the National Energy Administration, and water resource-relevant projects have mainly been mastered by the Ministry of Ecology and Environment and the Ministry of Water Resources. Therefore, dam projects will be considered differential according to their mastered ministries for e-flow implementation 
in future research. In this paper, the indicator criteria for classification was hypothesized based on existing research. A 0.5 value was set as the threshold for $D_{m}$ and $D_{\max }$, and 0.75 was set as the threshold for $D_{a}$, which is mainly based on the threshold of the IHA and RVA. Even though they have been applied in many studies, some thresholds should be further proved, such as the range of hydrological alteration [52]. The watershed diversity of the threshold values should be considered. The hydro-station distribution and hydrological data were not available, which resulted in difficulties in terms of hydrological alteration in watershed implementation, and higher accuracy hydrological simulation tools for assessing e-flow were in need [53].

Dams can reduce fish access to floodplain habitats that are essential nursery areas and feeding grounds. In this paper, only fish fauna was considered in terms of hydrobiological characteristics for classifying sensitive ecological water demand. For biodiversity protection, avifauna in wetlands should also be considered if possible. We determined ecohydrology relationships between Xiaolangdi Dam operation and the avifauna response of four downstream wetlands. The results showed a good correlation between ecological regulation and the quality of the wetlands and species of avifauna. Since China's wetland conservation and protected avifauna is unavailable, we hope to take global wetland data into consideration. E-flow adaptive management exists in many countries. A transferable framework for implementation has been established in Europe, and e-flow has improved through ecological response monitoring [54]. Few large dams can finish an adaptive management cycle and have enough funds for ecological response monitoring. More funds are in need for e-flow implementation in China.

\section{Conclusions and Recommendations}

This study developed a dam classification method for environmental flow assessment and implementation. Based on an analysis of 773 dams in China applying criteria related to dam properties, the degree of hydrological alteration, and the conservation value and status of downstream river reaches, four management classes were established. A minimum flow of 5-10\% of annual average flow has been the official demand for e-flow release during the last 10 years of practice. However, considering the diversity of dam classes identified, the single threshold is not sufficient to achieve the sustainable development goals of 2030. This study provides a classification framework to assist in improving national e-flow management, technically supporting watershed and regional e-low assessment. In e-flow assessment and implementation of specific dams, ecological investigations and monitoring still need to be implemented according to the established protection objects and ecohydrology relationships between e-flow and environmental objects. Because of the limited e-flow research, management, and practice in dam projects, comprehensive adaptive management is needed for future implementation. We recommend five topics for future research.

\subsection{Systematic River Conservation and Habitat Restoration}

Combined with existing practices on river ecosystem conservation, multi-ministry coordination of e-flow monitoring and management should be considered in an integrated network. Based on the systematic monitoring of river hydrology, sediment, water quality, sensitive objects, and dam operation, determination methods of the priority protection segments of fish habitats should be improved. In addition, tributary habitat alternative research and the fish habitat protection and restoration of mainstreams and tributaries should be improved.

\subsection{E-Flow Optimizing Benefits and Cost Evaluation}

E-flow optimization results in hydroelectricity loss and ecological improvement. Since legal e-flow levels of existing dams have already been set, it is difficult to change them, especially to raise the threshold values of minimum flow. In order to improve e-flow release, ecological benefits and the hydroelectricity cost evaluation of e-flow optimizations need to be estimated and determined. Only by integrating e-flow regulation into the unified electricity deployment of grid dispatch can e-flow be 
improved. With the gradual protection of ecological compensation mechanisms, coupled with constant encouragement toward hydropower station owners, the e-flow duration curve could be improved and optimized.

\subsection{E-Flow Guarantee and E-Flow Storage Capacity}

One difficulty in e-flow management was that the e-flow was not included or guaranteed in the design of most dams from the beginning. Though water for irrigation, urban water use, and industrial water use have been guaranteed, e-flow has not been considered in the design stage. E-flow should be $100 \%$ guaranteed in theoretical design, but this is usually the case with reservoir inflow, while the inflow is lower than e-flow in practice. Therefore, it is urgent that e-flow guarantees in the design period be implemented as soon as possible, and that integration with e-flow regulation capacity design be enhanced. E-flow should be considered in the master planning of water resource allocation in watershed water use, and e-flow duration curve optimization and e-flow regulation should be systematically integrated into the design to guarantee e-flow improvement.

\subsection{Multi-Threshold Value Determination Method}

The minimum e-flow was always efficient in e-flow management. To improve the single threshold value applied in national e-flow management, four thresholds of the four dam classes should be determined in future research. E-flow regionalization and regional e-flow threshold values have been discussed, and the results were not good $[55,56]$. For further e-flow research in classified dams, the threshold value for each class should be discussed. The existing e-flow threshold value determination method is based on regression analysis and cumulative frequency analysis of e-flow in operated projects, and the multi-threshold value of each category should be scientifically based on water-sensitive objects.

\subsection{Avifauna and Wetland Indicators Integration}

Except for rare and endangered fishes, downstream wetlands or floodplains are another sensitive object that needs more attention. Fish fauna and avifauna in the wetlands demand an e-flow duration curve. The international important wetlands and their fish fauna and avifauna should be considered in further research. Integrated with the classification method, more typical indicators should be considered for establishing a rapid and holistic classification method.

Supplementary Materials: The following are available online at http://www.mdpi.com/2071-1050/12/1/107/s1, Table S1: Attributes provided in the point layer of the China Reservoirs and Dams Database (CR\&D_Database); Table S2: China Reservoirs and Dams Database (CR\&D_Database); Table S3: The List of Wildlife under Special State Protection (PISCES, APPENDICULARIA); Table S4: Chinese red data of endangered animals: PISCES; Table S5: Fish Hotspots areas in China; Table S6: Fish habitats rescue protection segments; Table S7: List of rare and endangered fish species distribution; Table S8: Rare and endangered fish species distribution.

Author Contributions: Writing—original draft preparation, A.C. and M.W.; writing—review and editing, M.E.M. All authors have read and agreed to the published version of the manuscript.

Funding: This research was funded by National Key Research and Development Program of China, grant number 2016YFC0401708 and 2018YFE0196000.

Acknowledgments: The authors are grateful for the guidance of Wengen Liao from the General Institute of Water Resources and Hydropower Planning and Design, Ministry of Water Resources, for Kaiqi Chen from the Appraisal Center for Environment and Engineering (ACEE), Ministry of Ecology and Environment, for Zhiyu Sun and from the China Three Gorges Corporation, and for Xingnan Zhang from Hohai University. The authors are also grateful for the dataset provided by the International Commission on Large Dams (http://sedac.ciesin.columbia.edu/data/ collection/grand-v1), the National Earth System Science Data Sharing Infrastructure (http://www.geodata.cn), the Cold and Arid Regions Science Data Center at Lanzhou (http://westdc.westgis.ac.cn), Hohai University, the World Wildlife Fund (WWF), the Nature Conservancy (TNC), and the Land Surface Processes and Global Change Research Group at the Institute of Geographic Science and Natural Resources Research (IGSNRR), Chinese Academy of Sciences (CAS) (http://hydro.igsnrr.ac.cn).

Conflicts of Interest: The authors declare no conflict of interest. 


\section{References}

1. Berga, L.; Buil, J.M.; Bofill, E.; De Cea, J.C.; Perez, G.; Mañueco, G.; Polimon, J.; Soriano, A.; Yagüe, J. Dams and Reservoirs, Societies and Environment in the 21st Century; CRC Press: Boca Raton, FL, USA, 2006.

2. Chen, A.; Wen, J.; Wu, M.; Wang, P. Review of global and China's policies on fish passages. Water Policy 2019, 21, 708-721. [CrossRef]

3. International Hydropower Association. 2018 Hydropower Status Report; International Hydropower Association: London, UK, 2018.

4. World Commission on Dams. Dams and Development: A New Framework for Decision Making; World Commission on Dams: Cape Town, South Africa, 2000.

5. Chen, A.; $\mathrm{Wu}, \mathrm{M}$. Managing for Sustainability: The Development of Environmental Flows Implementation in China. Water 2019, 11, 433. [CrossRef]

6. Cumberlidge, N.; Peter, K.L.N.; Yeo, D.C.J.; Magalhãesc, C.; Campos, M.R.; Alvareze, F.; Naruseb, T.; Daniels, S.R.; Esser, L.J.; Attipoe, F.Y.K.; et al. Freshwater crabs and the biodiversity crisis: Importance, threats, status, and conservation challenges. Biol. Conserv. 2009, 142, 1665-1673. [CrossRef]

7. Liermann, C.R.; Nilsson, C.; Robertson, J.; Ng, R.Y. Implications of Dam Obstruction for Global Freshwater Fish Diversity. BioScience 2012, 62, 539-548. [CrossRef]

8. Opperman, J. The Power of Rivers: A Business Case; The Nature Conservancy: Arlington County, VA, USA, 2017.

9. Arthington, A.H. Environmental Flows: Saving Rivers in the Third Millennium, 30; University of California Press: Berkeley, CA, USA, 2012.

10. Richter, B.D.; Warner, A.T.; Meyer, J.L.; Lutz, K. A collaborative and adaptive process for developing environmental flow recommendations. River Res. Appl. 2006, 22, 297-318. [CrossRef]

11. McManamay, R.A.; Oigbokie, C.O.; Kao, S.C.; Bevelhimer, M.S. Classification of US Hydropower Dams by their Modes of Operation. River Res. Appl. 2016, 32, 1450-1468. [CrossRef]

12. Pahl-Wostl, C.; Arthington, A.; Bogardi, J.; Bunn, S.E.; Hoff, H.; Lebel, L.; Nikitina, E.; Palmer, M.; Poff, L.N.; Richards, K.; et al. Environmental flows and water governance: Managing sustainable water uses. Curr. Opin. Environ. Sustain. 2013, 5, 341-351. [CrossRef]

13. Junna, W.; Dong, Z.; Liao, W.; Li, C.; Feng, S.; Luo, H.; Peng, Q. An environmental flow assessment method based on the relationships between flow and ecological response: A case study of the Three Gorges Reservoir and its downstream reach. Sci. China Technol. Sci. 2013, 6, 715-726.

14. Ang, C.; Chen, S.; Miao, W.; Pengyuan, W. Recommendation on Ecological Water Demand Management in China. Sci. Technol. Rev. 2016, 22, 11.

15. Ang, C.; Miao, W.; Chen, S.; Zhang, X.; Wang, P. Review of Method for Calculation of River Ecological Base-flow and Study on Its Assessment Framework. Water Resour. Hydropower Eng. 2017, 2, 97-105.

16. Gillilan, D.M.; Brown, T.C. Instream Flow Protection. Restor. Ecol. 1997, 7, 100-101.

17. Pittock, J.; Hartmann, J. Taking a second look: Climate change, periodic relicensing and improved management of dams. Mar. Freshw. Res. 2011, 62, 312-320. [CrossRef]

18. Department of Environmental Impact Assessment State Environmental Protection Administration, P.R.C. Research and Practice of Ecological Protection for Water Resources \& Hydropower Development Projects; China Environmental Science Press: Beijing, China, 2006.

19. Wu, M.; Chen, A. Practice on ecological flow and adaptive management of hydropower engineering projects in China from 2001 to 2015. Water Policy 2017, 2, 336-354. [CrossRef]

20. Grantham, T.E.; Viers, J.H.; Moyle, P.B. Systematic Screening of Dams for Environmental Flow Assessment and Implementation. BioScience 2014, 64, 1006-1018. [CrossRef]

21. Mathews, R.; Richter, B.D. Application of the Indicators of Hydrologic Alteration Software in Environmental Flow Setting1; Blackwell Publishing Ltd.: Hoboken, NJ, USA, 2007; pp. 1400-1413.

22. Chen, A.; Wu, M.; Chen, K.-Q.; Sun, Z.-Y.; Chen, S.; Wang, P.-Y. Main issues in research and practice of environmental protection for water conservancy and hydropower projects in China. Water Sci. Eng. 2016, 9, 312-323. [CrossRef]

23. Gangloff, M.M. Taxonomic and ecological tradeoffs associated with small dam removals. Aquat. Conserv. Mar. Freshw. Ecosyst. 2013, 23, 475-480. [CrossRef]

24. Smith, S.V.; Renwick, W.H.; Bartley, J.D.; Buddemeier, R.W. Distribution and significance of small, artificial water bodies across the United States landscape. Sci. Total Environ. 2002, 299, 21. [CrossRef] 
25. Günther, G.A.B.L. An index-based framework for assessing patterns and trends in river fragmentation and flow regulation by global dams at multiple scales. Environ. Res. Lett. 2015, 10, 015001.

26. Batalla, R.J.; Gómez, C.M.; Kondolf, G.M. Reservoir-induced hydrological changes in the Ebro River basin (NE Spain). J. Hydrol. 2004, 290, 117-136. [CrossRef]

27. Eng, K.; Carlisle, D.M.; Wolock, D.M.; Falcone, J.A. Predicting the likelihood of altered streamflows at ungauged rivers across the conterminous. USA River Res. Appl. 2013, 29, 781-791. [CrossRef]

28. Alcamo, J.; Doll, P.; Henrichs, T.; Kaspar, F.; Lenhner, B.; Rosch, T.; Siebert, S. Development and testing of the WaterGAP 2 global model of water use and availability. Hydrol. Sci. J. 2003, 48, 317-337. [CrossRef]

29. Lehner, B.; Verdin, K.; Jarvis, A. New Global Hydrography Derived from Spaceborne Elevation Data. Eos Trans. Am. Geophys. Union 2008, 89, 93-94. [CrossRef]

30. Zhang, X.; Tang, Q.; Pan, M. A Long-Term Land Surface Hydrologic Fluxes and States Dataset for China. In Proceedings of the EGU General Assembly Conference, Vienna, Austria, 27 April-2 May 2014.

31. Sanborn, S.C.; Bledsoe, B.P. Predicting streamflow regime metrics for ungauged streamsin Colorado, Washington, and Oregon. J. Hydrol. 2006, 325, 241-261. [CrossRef]

32. Kennen, J.G.; Kauffman, L.J.; Ayers, M.A.; Wolock, D.M.; Colarullo, S.J. Use of an integrated flow model to estimate ecologically relevant hydrologic characteristics at stream biomonitoring sites. Ecol. Model. 2008, 211, 57-76. [CrossRef]

33. Singh, V.P.; Frevert, D.K.; Singh, V.P.; Frevert, D.K. Mathematical modeling of watershed hydrology. J. Hydrol. Eng. 2002, 7, 270-292. [CrossRef]

34. Wu, M.; Shi, P.; Chen, A.; Shen, C.; Wang, P. Impacts of DEM resolution and area threshold value uncertainty on the drainage network derived using SWAT. Water SA 2017, 43, 450-462. [CrossRef]

35. Esselman, P.C.; Infante, D.M.; Wang, L.; Cooper, A.R.; Wieferich, D.; Tsang, Y.-P.; Thornbrugh, D.J.; Taylor, W.W. Regional fish community indicators of landscape disturbance to catchments of the conterminous. USA Ecol. Indic. 2013, 26, 163-173. [CrossRef]

36. Moyle, P.B.; Katz, J.V.E.; Quiñones, R.M. Rapid decline of California's native inland fishes: A status assessment. Biol. Conserv. 2011, 144, 2414-2423. [CrossRef]

37. Carlisle, D.M.; Wolock, D.M.; Meador, M.R. Alteration of streamflow magnitudes and potential ecological consequences: A multiregional assessment. Front. Ecol. Environ. 2011, 9, 264-270. [CrossRef]

38. Konrad, C.P.; Brasher, A.M.D.; May, J.T. Assessing streamflow characteristics as limiting factors on benthic invertebrate assemblages in streams across the western United States. Freshw. Biol. 2008, 53, 1983-1998. [CrossRef]

39. Richter, B.D.; Davis, M.M.; Apse, C.; Konrad, C. A Presumptive Standard for Environmental Flow Protection. River Res. Appl. 2012, 28, 1312-1321. [CrossRef]

40. Ministry of Water Resources, P.R.C.; National Bureau of Statistics, P.R.C. Bulletin of First National Census for Water; China Water \& Power Press: Beijing, China, 2013; 20p.

41. Lehner, B.; Liermann, C.R.; Revenga, C.; Vörösmarty, C.; Fekete, B.; Crouzet, P.; Döll, P.; Endejan, M.; Frenken, K.; Magome, J.; et al. High-Resolution Mapping of the World's Reservoirs and Dams for Sustainable River-Flow Management; European Space Agency: Paris, France, 2011; Volume 9, pp. 494-502.

42. Lehner, B.; Liermann, R.; Revenga, C.; Vörösmarty, C.; Fekete, B.; Crouzet, P.; Döll, P.; Endejan, M.; Frenken, K.; Magome, J.; et al. Global Reservoir and Dam Database; Version 1: Dams, Revision 01; GDW: Palisades, NY, USA, 2011.

43. Lei, C. Estabilishment and Application of the Fundamental Geography Database of the Rare and Special Fish on the Upper Reaches of the Yangtze. Master's Thesis, Huazhong Agricultural University, Wuhan, China, 2010.

44. Santos, N.R.; Katz, J.V.E.; Moyle, P.B.; Viers, J.H. A programmable information system for management and analysis of aquatic species range data in California. Environ. Model. Softw. 2014, 53, 13-26. [CrossRef]

45. Vorosmarty, C.J.; McIntyre, P.B.; Gessner, M.O.; Dudgeon, D.; Prusevich, A.; Green, P.; Glidden, S.; Bunn, S.E.; Sullivan, C.A.; Liermann, C.R.; et al. Global threats to human water security and river biodiversity. Nature 2010, 467, 555-561. [CrossRef]

46. Syvitski, J.P.M.; Kettner, A.J.; Overeem, I.; Hutton, E.W.H.; Hannon, M.T.; Brakenridge, G.R.; Day, J.; Vörösmarty, C.; Saito, Y.; Giosan, L.; et al. Sinking deltas due to human activities. Nat. Geosci. 2009, 2, 681. [CrossRef] 
47. Grill, G.; Ouellet Dallaire, C.; Fluet Chouinard, E.; Sindorf, N.; Lehner, B. Development of new indicators to evaluate river fragmentation and flow regulation at large scales: A case study for the Mekong River Basin. Ecol. Indic. 2014, 45, 148-159. [CrossRef]

48. Chen, A.; Sui, X.; Wang, D.; Liao, W.; Ge, H.; Tao, J. Landscape and avifauna changes as an indicator of Yellow River Delta Wetland restoration. Ecol. Eng. 2016, 86, 162-173. [CrossRef]

49. Jin, C.; Li, Q. Assessment of eco-operation effect of Three Gorges Reservoir during trial run period. J. Yangtze River Sci. Res. Inst. 2015, 32, 1-6.

50. Erfani, T.; Binions, O.; Harou, J.J. Protecting environmental flows through enhanced water licensing and water markets. Hydrol. Earth Syst. Sci. 2015, 19, 675-689. [CrossRef]

51. Harwood, A.; Johnson, J.; Richter, B.; Locke, A.; Yu, X.; Tickner, D. Listen to the River: Lessons from a Global Review of Environmental Flow Success Stories; WWF-UK: Woking, Surrey, UK, 2017.

52. Meitzen, K.M. Stream flow changes across North Carolina (USA) 1955-2012 with implications for environmental flow management. Geomorphology 2016, 252, 171-184. [CrossRef]

53. Steinfeld, C.M.M.; Kingsford, R.T.; Webster, E.C.; Sharma, A. A simulation tool for managing environmental flows in regulated rivers. Environ. Model. Softw. 2015, 73, 117-132. [CrossRef]

54. Summers, M.F.; Holman, I.P.; Grabowski, R.C. Adaptive management of river flows in Europe: A transferable framework for implementation. J. Hydrol. 2015, 531, 696-705. [CrossRef]

55. Alcázar, J.; Palau, A. Establishing environmental flow regimes in a Mediterranean watershed based on a regional classification. J. Hydrol. 2010, 388, 41-51. [CrossRef]

56. Chen, A.; Wu, M.; Wu, S.-N.; Sui, X.; Wen, J.-Y.; Wang, P.-Y.; Cheng, L.; Lanza, G.R.; Liu, C.-N.; Jia, W.-L. Bridging gaps between environmental flows theory and practices in China. Water Sci. Eng. 2019. [CrossRef]

(C) 2019 by the authors. Licensee MDPI, Basel, Switzerland. This article is an open access article distributed under the terms and conditions of the Creative Commons Attribution (CC BY) license (http://creativecommons.org/licenses/by/4.0/). 